\title{
The Effect of Blend Fuel Waste Plastic and Waste Cooking Oil on Diesel Engine Performance Based on Simulation
}

\author{
Aguk Zuhdi Muhammad Fathallah ${ }^{1}$, Adhi Iswantoro ${ }^{2}$, A Karomur Roziq F ${ }^{3}$ \\ (Received: 24 August 2020 / Revised: 28 August 2020 / Accepted: 31 August 2020)
}

\begin{abstract}
- nowadays, polypropylene plastics are very often found and cause various environmental problems. Though it is known that along with polypropylene itself comes from propylene monomers obtained from refining petroleum. Besides the use of waste cooking, biodiesel fuel has many drawbacks, one of which is power and fuel consumption. Mixing polypropylene plastic waste for reuse with waste cooking oil biodiesel is an option. This study uses five variations of fuel, namely HSD, B30, C20, C30, and C40, a combination of HSD, waste cooking, and polypropylene. This research is based on experiments to analyze the impact of using these five variations of fuel on the performance diesel engines based on simulation. The performance of the diesel engine would be measured to SFOC, power, and torque produced by each fuel. Based on the results of the analysis of the performance of the diesel engine performance of $\mathrm{C20}$, fuel can be the most optimum alternative fuel to the substitute B30, producing $6.0 \mathrm{~kW}$ of power, $238 \mathrm{gr} / \mathrm{kWh}$ of SFOC, and $31.7 \mathrm{Nm}$ of torque.
\end{abstract}

Keywords - combustion process, emissions, performance, polypropylene, waste cooking oil.

\section{INTRODUCTION}

Non-renewable fossil energy resources encourage humans to replace them from fossil hydrocarbons to renewable fuels to meet the needs of energy resources [1]. Energy needs by depleting natural resources have resulted in a significant greenhouse gas effect, emissions, and anthropogenic climate change [2]. The world's petroleum reserves at the end of 2014 amounted to 1700.1 billion barrels, while Indonesia only had proven oil reserves of 3.7 billion barrels. This encourages the emergence of policies on sustainable energy to reduce greenhouse gas emissions and produce renewable energy from sources such as wind, solar, geothermal, and waste energy.

In 2016, Indonesia became the second-largest plastic waste-producing country in the world, with 187.2 million tons of plastic waste, after China, with 262.9 million tons of plastic waste [3]. Plastic products have a very short lifespan and mostly end up in landfills. Plastic waste has environmental and operational problems in landfills due to the slow degradation rate and presence of toxic dyes and additives [4]. Nowadays, polypropylene (PP) type plastic in Indonesia is very often to use. The next problem arising from this type of plastic is the waste that is generated; the reuse of this type of waste is still very rare. It is already known polypropylene itself comes from propylene monomers obtained from refining petroleum.

Aguk Zuhdi M. Fathallah is with Department of Marine Engineering, Institut Teknologi. Sepuluh Nopember, Surabaya, 60111, Indonesia.E-mail: fathalaz@its.ac.id

Adhi Iswantoro is with Department of Marine Engineering, Institut Teknologi. Sepuluh Nopember, Surabaya, 60111, Indonesia. E-mail: adhi@ne.its.ac.id

A Karomur Roziq F is with Department of Marine Engineering, Institut Teknologi. Sepuluh Nopember, Surabaya, 60111, Indonesia. Email: Karomur.roziq@gmail.com
Biodiesel is one of the alternative fuels that is currently being discussed in addition to renewable Biodiesel. Biodiesel can be used just like conventional fuels that can be used in diesel engines and have emissions that are quite environmentally friendly compared to conventional fuels such as carbon. However, other studies have shown that when compared to HSD, B10 has several results where lower thermal efficiency, higher BSFC, higher NOx, besides also having lower $\mathrm{CO}$ and $\mathrm{HC}$ emission [5].

As we concluded polypropylene and wasted cooking oil fuel, it can be predicted that it can increase the calorific value, but the viscosity of the mixed fuel will increase. So in this research, an alternative fuel will be made by mixing used cooking oil with polypropylene and water as additives. Here polypropylene is chosen because recently, there is a lot of plastic waste in Indonesia, and also polypropylene can be used as a mixture of high-speed diesel fuel. In past research, research has been carried out by mixing diesel oil with polypropylene to determine which surfactants can emulsify polypropylene and used cooking oil stably and adequately. Still, there have been no results regarding the performance of diesel engines using this mixture.

\section{METHOD}

\section{A. Research Problem}

The research is done by digging up information by studying studies that have been carried out previously. The author obtained the problem formulation in the development of several studies that have been carried out already, namely, a mixture of polypropylene plastic waste and used cooking to produce liquid fuel [6]. In other research, it has been proven that a mix of polypropylene plastic waste and used cooking can produce liquid fuel. So that in this paper, the writer develops the idea to analyze the impact of the fuel 


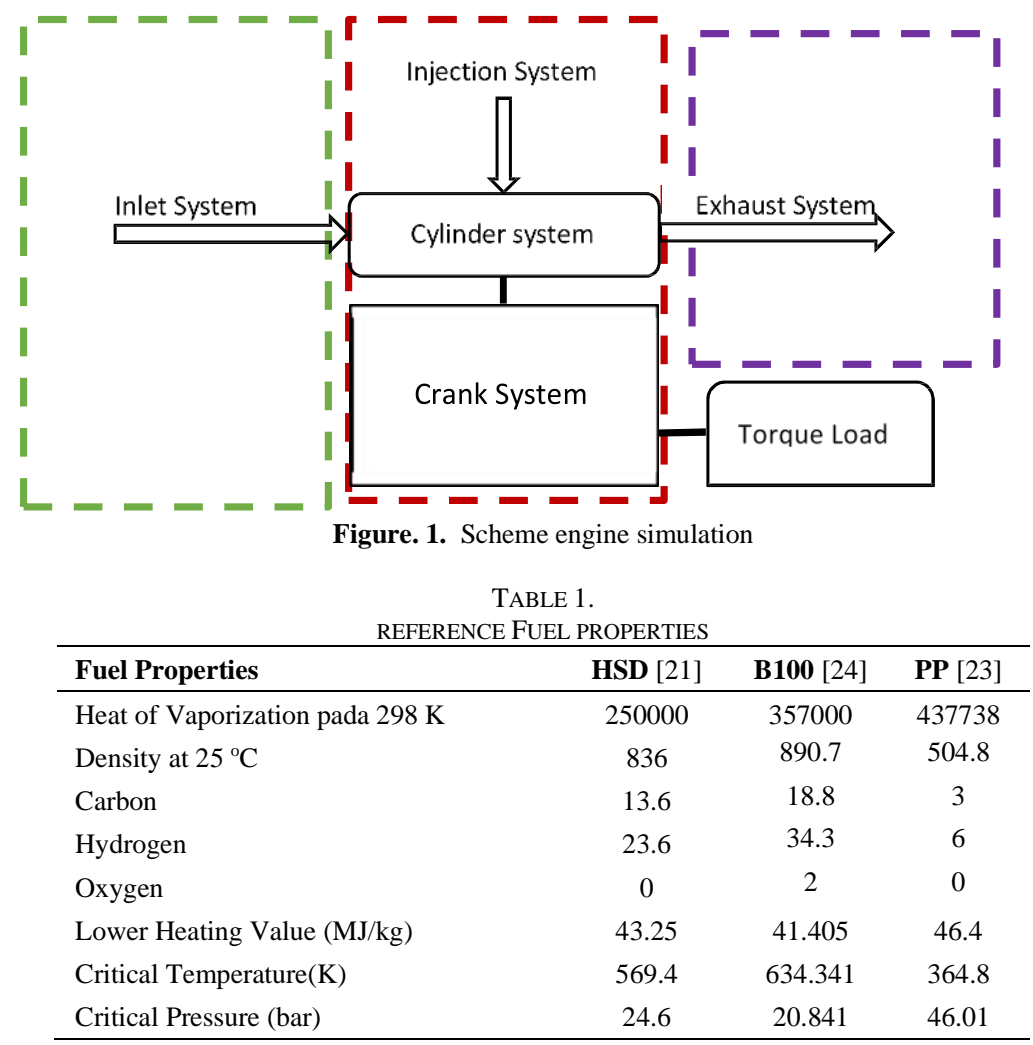

directly on the tuned engine, which includes performance, combustion process, and the resulting emissions, by variating and mixing both PP-WCO and variations.

\section{B. Collecting Data}

In this research, several literature studies are needed in the simulation process. Likewise, the data required in this study are as follows:

\section{Software Simulation Method}

Based on a study, the device methods used for simulation include combustion, burn rate, heat release rate, apparent heat rate, where the combustion process refers to the amount of fuel that is burned or the fuel that is unburned in the cylinder, which releases chemical energy from the mixture of air and fuel by a formula based on characteristics of the fuel [7].

In the simulation software, there are four stages in the process to achieve the simulation

a. At the start of combustion (the spark in the SI engine, or the start of injection in the DI engine), the cylinder is divided into two zones: an unburned zone and a burned zone. All of the contents of the cylinder at that time start in the unburned zone, including residual gases from the previous cycle and EGR.

b. At each time step, a mixture of fuel and air is transferred from the unburned zone to the burned zone. The amount of fuel-air mixture that is transferred to the burned zone is defined by the burn rate. This burn rate is prescribed (or calculated by) the combustion model.

c. Once the unburned fuel and associated air have been transferred from the unburned zone to the burned zone in a given time step, a chemical equilibrium calculation is carried out for the entire "lumped" burned zone. This calculation takes into account all of the atoms of each species $(\mathrm{C}, \mathrm{H}, \mathrm{O}, \mathrm{N}, \mathrm{S}$, Ar) present in the burned zone at that time, and obtains from these an equilibrium concentration of the 13 products of combustion species $(\mathrm{N} 2, \mathrm{O} 2, \mathrm{H} 2 \mathrm{O}, \mathrm{CO} 2$, $\mathrm{CO}, \mathrm{H} 2, \mathrm{~N}, \mathrm{O}, \mathrm{H}, \mathrm{NO}, \mathrm{OH}, \mathrm{SO} 2, \mathrm{Ar})$. The equilibrium concentrations of the species depend strongly on the current burned zone temperature and, to a lesser degree, the pressure.

d. Once the new composition of the burned zone has been obtained, the internal energy of each species is calculated. Then, the energy of the whole burned zone is obtained by summation over all of the species. Applying the principle that energy is conserved, the new unburned and burned zone temperatures and cylinder pressure are obtained.

\section{Engine Specification}

Engine specifications are obtained from the Yanmar TF85MH manual book shown in table 3 .

TABLE 3.

YANMAR TF85MH SPECIFICATION

\begin{tabular}{lll}
\hline 1 & Total cylinder & One cylinder \\
2 & Injection & $18 \mathrm{deg}$ before TMA \\
3 & Bore x Stroke & $85 \mathrm{~mm} \times 87 \mathrm{~mm}$ \\
4 & Volume cylinder & $493 \mathrm{cc}$ \\
\hline
\end{tabular}




\begin{tabular}{lll}
\hline 5 & Compression ratio & $18: 1$ \\
6 & Power & $8,5 \mathrm{dk} / 2200 \mathrm{rpm}$ \\
7 & Torque & $3,44 \mathrm{kgm}-/ 1600 \mathrm{rpm}$ \\
8 & SFOC & $171 \mathrm{gr} / \mathrm{kWh}$ \\
\hline
\end{tabular}

3. Fuel Characteristics

As data input to the software, the composition of the fuel has to be used is required, WCO, HSD, and PP. with the characteristics according to table 4

TABLE 4 .

\begin{tabular}{cccc}
\multicolumn{4}{c}{ REFERENCE FUEL PROPERTIES } \\
\hline $\begin{array}{c}\text { Fuel } \\
\text { Properties }\end{array}$ & C20 & C30 & C40 \\
\hline $\begin{array}{c}\text { Lower Heating } \\
\text { Value (MJ/kg) } \\
\text { Critical }\end{array}$ & 42.965 & 42.035 & 41.105 \\
$\begin{array}{c}\text { Temperature(K) } \\
\text { Critical }\end{array}$ & 551.314 & 593.421 & 635.528 \\
Pressure (bar) & 28.517 & 25.123 & 21.729 \\
\hline
\end{tabular}

TABLE 5 .

COMPOSITION FUEL PROPERTIES

\begin{tabular}{cccc}
\hline Fuel & HSD & WCO & PP \\
\hline HSD & 100 & 0 & 0 \\
B30 & 70 & 30 & 0 \\
C20 & 50 & 20 & 30 \\
C30 & 50 & 30 & 20 \\
C40 & 50 & 40 & 10
\end{tabular}

TABLE 6.

\begin{tabular}{cccc}
\multicolumn{4}{c}{ COMPOSITION FUEL PROPERTIES SIMULATION } \\
\hline $\begin{array}{c}\text { Fuel } \\
\text { Properties }\end{array}$ & C20 & C30 & C40 \\
\hline $\begin{array}{c}\text { Lower Heating } \\
\text { Value }(\mathrm{MJ} / \mathrm{kg})\end{array}$ & 42.965 & 42.035 & 41.105 \\
$\begin{array}{c}\text { Critical } \\
\text { Temperature(K) } \\
\quad \text { Critical }\end{array}$ & 551.314 & 593.421 & 635.528 \\
Pressure (bar) & 28.517 & 25.123 & 21.729
\end{tabular}

\section{Yanmar TF 85 Engine Simulation Modeling}

Modeling is engineering as closely as possible to the design that has results experimentally obtained that can be maximally analyzed [11]. Modeling and simulation are carried out based on the previously designed motor specifications. In modeling and simulation, some steps must be taken to produce valid data for analysis. simulation components as follows below

1. Inlet system:

a. Intake port and runner

b. Inlet environment

2. Injection system

a. Cylinder b. Fuel injection

c. Engine Cranktrain

3. Outlet System:
a. Exhaust port and runner
b. Outlet environment

4. Load torque

\section{Data Validation}

Simulation-Based on data obtained from the Project guide / Manual guide of the Yanmar TF 85 engine as listed in table 5 with predetermined parameters such as

SFOC, Torque, Power, here are the results of the Yanmar TF 85 Diesel calibration simulation.

TABLE 7.

\begin{tabular}{lccc}
\multicolumn{4}{c}{ VALIDATING DATA SIMULATION } \\
\hline & Simulation & $\begin{array}{c}\text { Project } \\
\text { guide }\end{array}$ & $\begin{array}{c}\text { Margin } \\
\text { error }(\%)\end{array}$ \\
\hline Power(HP) & 8.59 & 8.5 & 1.07 \\
Torque (kgf-m) & 3.18 & 3.3 & 3.60 \\
SFOC (g/HP-h) & 171.38 & 171 & 0.01 \\
\hline
\end{tabular}

\section{E. Discussion and Conclusion}

When all the necessary data have been collected, it is followed by an analysis that will answer all the research objectives set by the author. Analysis can be carried out when all the necessary data have been collected. The results of the analysis must answer all of the research objectives set by the author. 


\section{RESULTS AND DISCUSSION}

A. SFOC Results on Power in HSD, B30, C20, C30, and $C 40$ fuels

It can be concluded that the greater the engine speed, the lower the SFOC value obtained. However, at 2000 RPM and 2200 RPM, the SFOC value increased compared to $1800 \mathrm{RPM}$. Increase of $1-2 \mathrm{~g} / \mathrm{kWh}$ This is due to engine overload. Where in the event that occurs after is an increase in increased fuel consumption

In each chart starting from HSD, B30, C20, C30, $\mathrm{C} 40$, there is a trendline that almost resembles the difference, namely the SFOC value and the power produced. It can be analyzed that each simulated fuel uses a precise calibration compared to the experimental results. Then by looking at the trendline graph of each fuel. Analysis can be drawn where each increase in RPM, the power generated also increases as well, while the resulting SFOC tends to reverse was at every RPM increase, the SFOC will decrease, then at each increase in load, the power the resulting product also increases as well as the SFOC will decrease. Thus, it can be concluded that in the analysis of the results of the performance of SFOC power and torque reach optimum at 2200 RPM and also at $100 \%$ load. The results show that the HSD produces the highest power and the lowest SFOC, where this HSD is included as a reference in the comparison. However, when compared to alternative fuels other than HSD, the C20 produces optimum values with low SFOC values and high power.

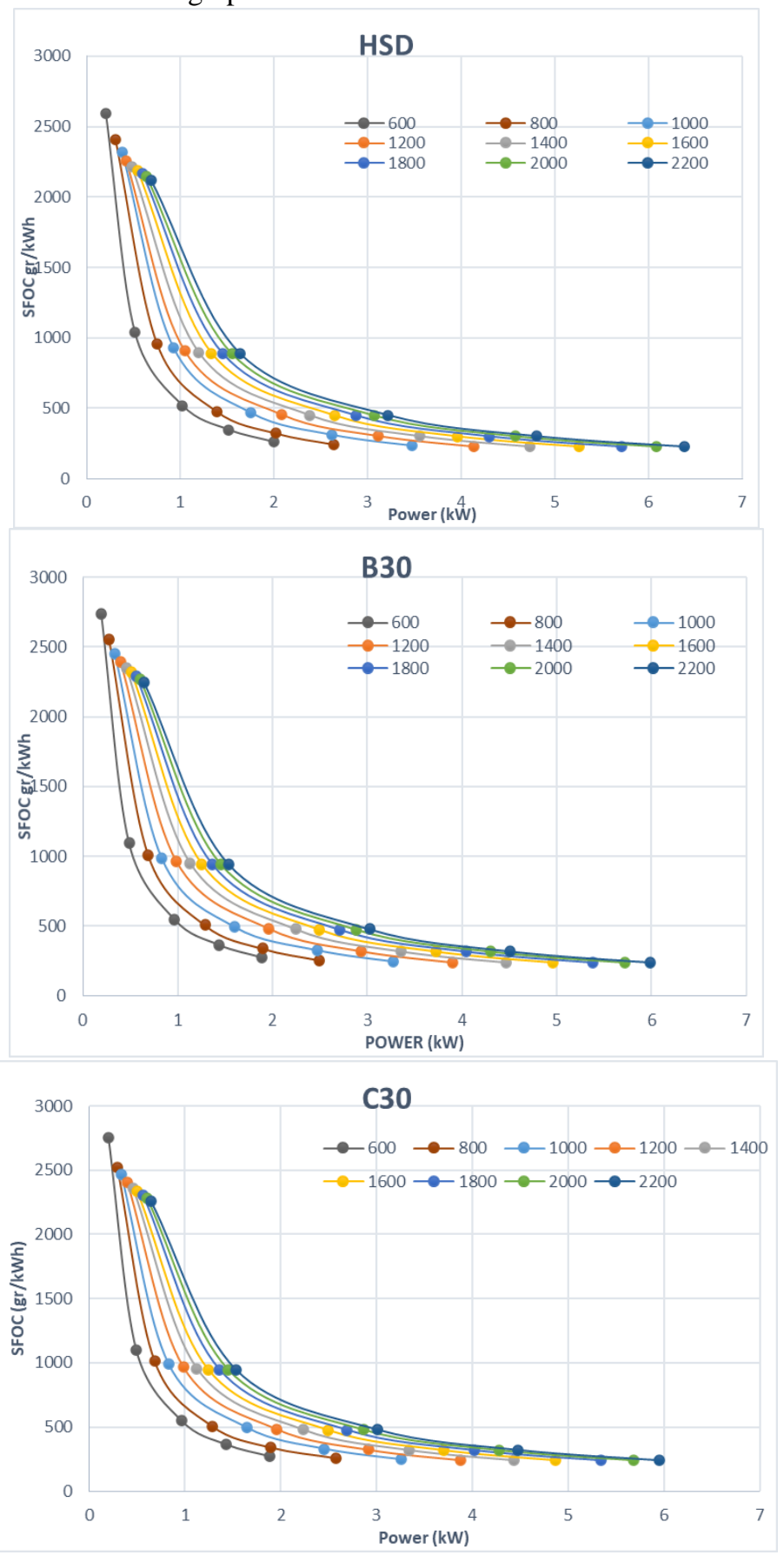



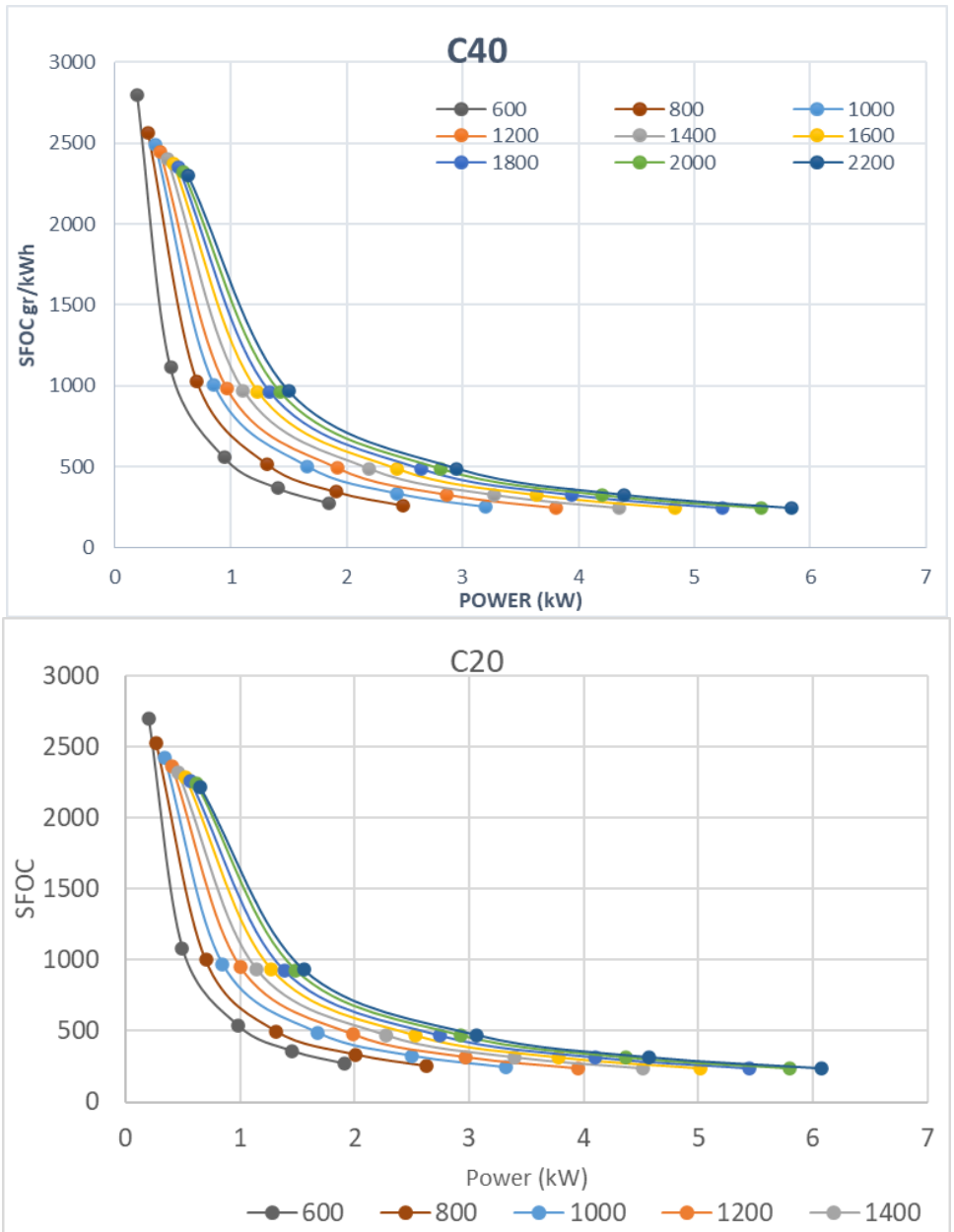

Figure. 1. Results fuel simulation Power and SFOC conditions to variations in Speed (RPM)

It can be concluded that in the analysis of the results of the performance of SFOC, power, and torque reach optimum at 2200 RPM and also at $100 \%$ load. The results show that the HSD produces the highest power and the lowest SFOC, where this HSD is included as a reference in the comparison. However, when compared to alternative fuels other than HSD, the C20 produces optimum values with low SFOC values and high-power. 

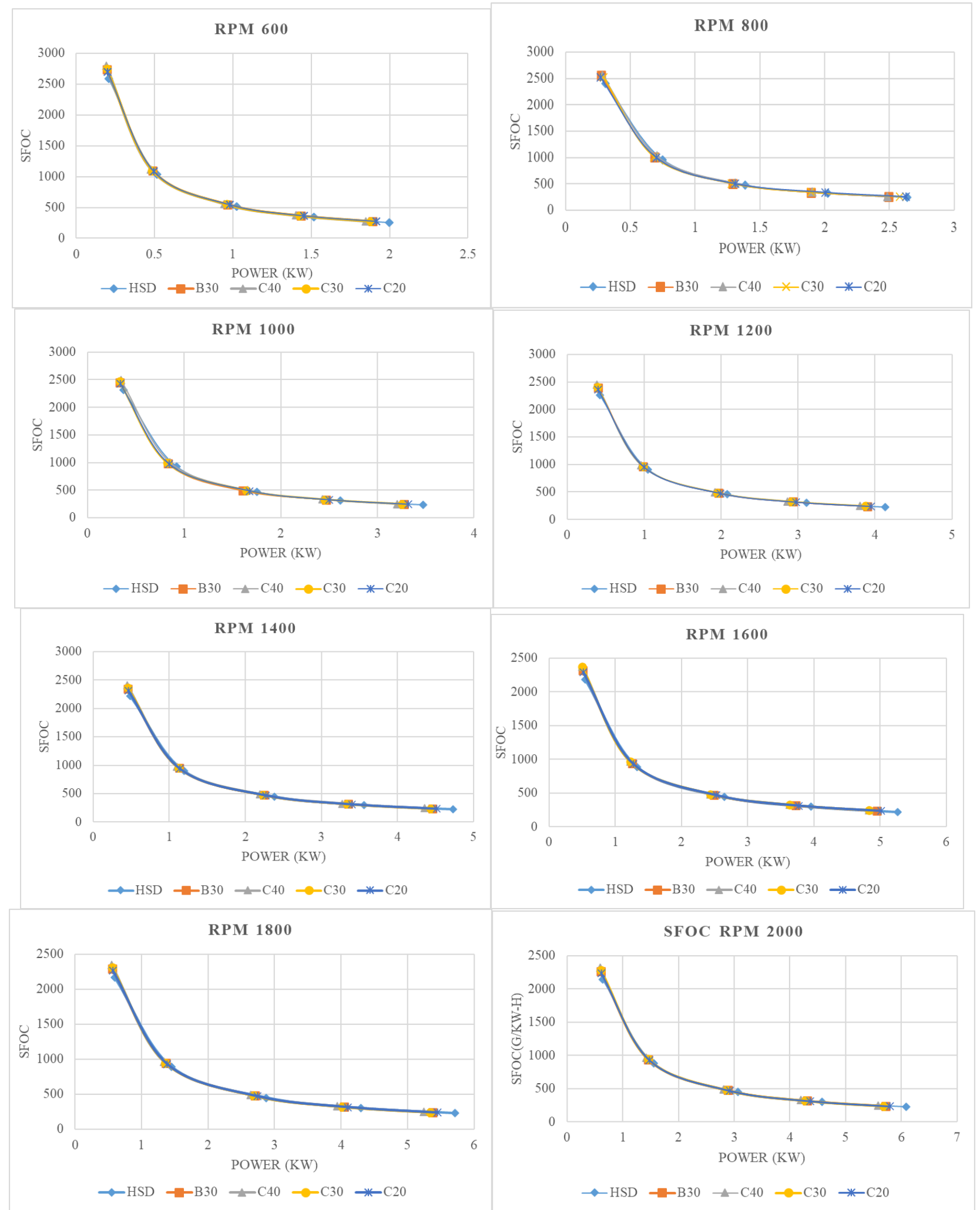

Figure. 2. Results comparing SFOC performance data with Power from RPM 600 to 2200

B. Results comparing SFOC performance data with Power from RPM 600 to 2200

In this research, a performance test will be carried out to determine the effect of the combination of polypropylene biodiesel with used cooking diesel engine with the characteristics of the Yanmar TF85-MH diesel motor. The rotation used in this experiment starts at 600 RPM, up to $2200 \mathrm{rpm}$ with a load variation of $10 \%, 25 \%$, $50 \%, 75 \%$, and $100 \%$. In this experiment, there are five types of fuel to be used, namely HSD, B30, C20, C30, and $\mathrm{C} 40$.

That each graph in Figure 7 to Figure 14 shows that every fuel at the same engine speed has a graphic that resembles one another and overlaps. This is because, in the graph, the resulting SFOCs resemble each other at any given load. However, at RPM, it can be seen that the power generated on the X-axis changes where the HSD as a reference produces the maximum power. And when 


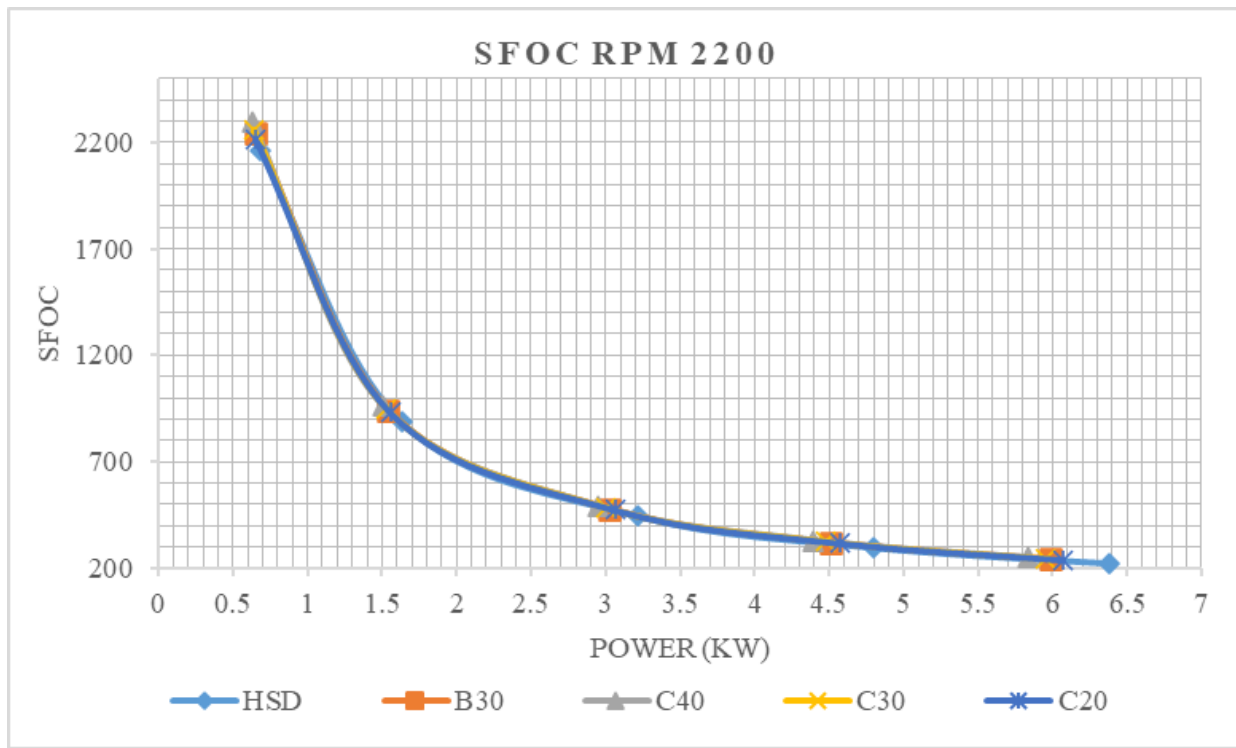

Figure. 3. Results comparing SFOC performance data with Power 2200 RPM

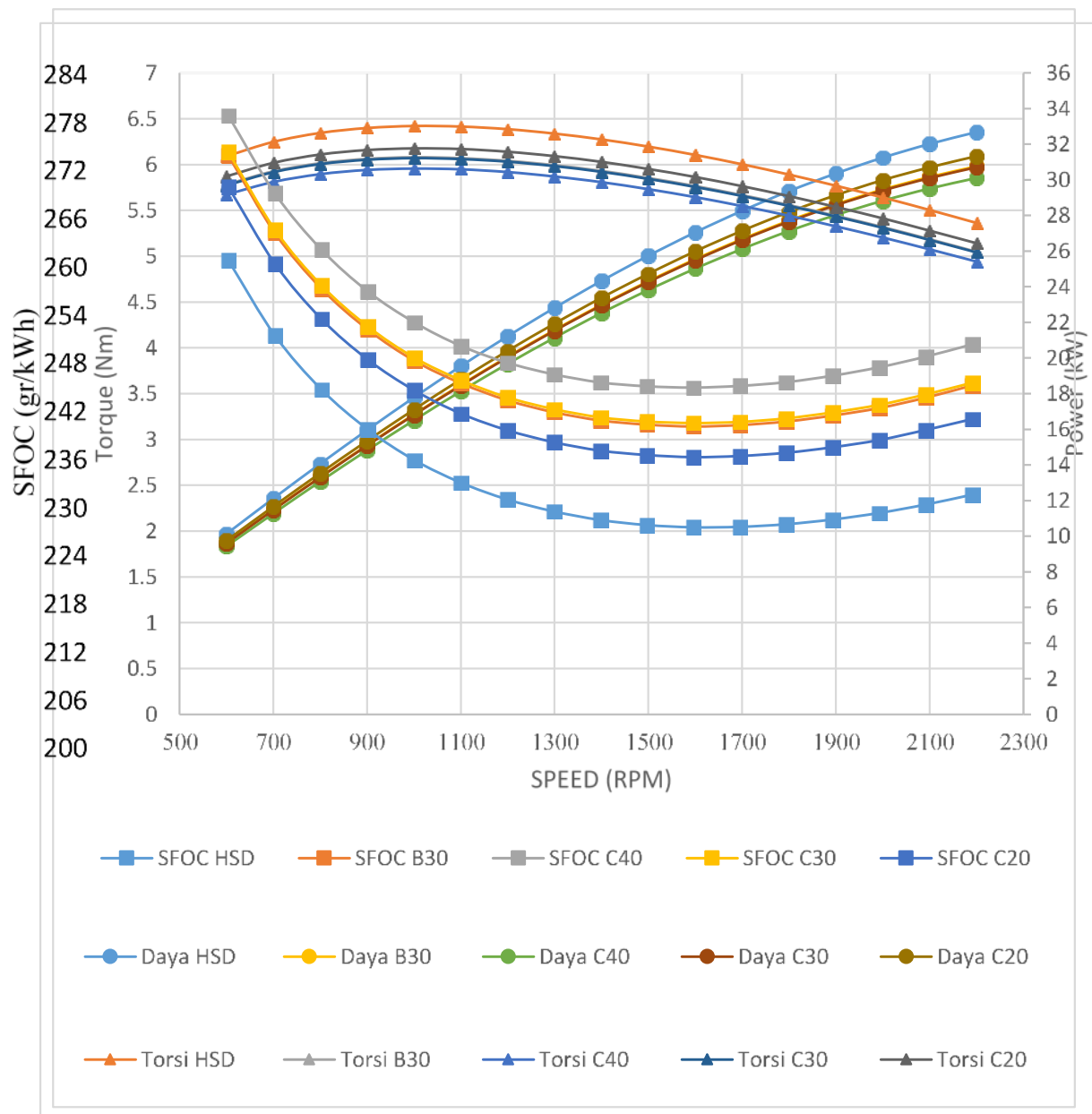

Figure. 4. Power, Torque, and SFOC at full load to various Speed (RPM)

compared to 4 alternative fuels other than HSD, C20 produces higher power than other alternative fuels.

As seen in graph 3, the trend patterns in all fuels are almost similar to each other because the power generated at 2200 RPM with load variations tends to resemble one another, but it is clear that there are differences in SFOC that are depicted. The difference in SFOC between fuels occurs because each fuel has a different heating value as an example of the alternative $\mathrm{C} 20$ fuel looks more optimal than other alternative fuels
From the graph 1, the comparison between engine speed to power at full load for all types of fuel is a graph of the comparison of the performance of engine speed to power in all types of fuel. This value is obtained from the lowest SFOC point described in the previous graphs. The highest or maximum power is obtained at $2200 \mathrm{rpm}$ for each fuel. By using HSD fuel, the maximum power of $6.35 \mathrm{~kW}$ is obtained. Combined, Biodiesel produces a maximum power of $\mathrm{C} 20, \mathrm{C} 30, \mathrm{C} 40$, respectively, which is $6.0 \mathrm{~kW}, 5.9 \mathrm{~kW}, 5.8 \mathrm{~kW}$, and for $\mathrm{B} 30$, it gets the 
power of $5.9 \mathrm{~kW}$. From the experiment using the five types of fuel, the power is obtained with a more or less constant increase of around $0.2-0.4 \mathrm{~kW}$ in every 100 RPM increase.

The torque from HSD, B30, C20, C30, and C40 fuels in Figure 4.15 can be concluded that the maximum torque is generated at an engine speed of 1000 RPM. The torque produced at $1000 \mathrm{RPM}$ rotation speed by HSD fuel is $33.0 \mathrm{Nm}, 1.3 \mathrm{Nm}$ higher than $\mathrm{C} 20$ fuel, which has $31.7 \mathrm{Nm}$ of torque and 2.9 Nm higher than B30 fuel with a torque of $31.1 \mathrm{Nm}$. Then, respectively C30 and C40 are $31.0 \mathrm{Nm}$ and $30.4 \mathrm{Nm}$, which means that the torque produced by HSD fuel is the largest torque compared to other fuels. However, when compared to the four alternative fuels, the $\mathrm{C} 20$ shows the highest value with a maximum torque produced at 1000 RPM 31.7 greater than $0.6 \mathrm{Nm}$. From the graph above, it can be seen that the trend of the graph increases at 600 to 1000 RPM, then after that from 1000 RPM to 2200 RPM, the torque decreases in RPM, which tends to be constant from 0.2$0.7 \mathrm{Nm}$.

The graph above is a graph that shows the comparison of each variable used for engine performance analysis, where the SFOC, Torque, and Power variables are fully loaded with RPM variations. It can be seen that in the SFOC graph, the trend in the graph tends to decrease with the addition of RPM, but the downward trend is. This shows that at the addition of RPM the less fuel consumption is used, but it can be seen in the graph trend that the lowest decrease is at RPM 1700 where the fuel consumption at that RPM is all fuel experiencing the lowest point, with a value of HSD 224 gr / kWh, C20 233 gr / kWh, B30 237 gr / kWh, C30 238 $\mathrm{gr} / \mathrm{kWh}$ and the highest fuel consumption is C40 with a value of $243 \mathrm{gr} / \mathrm{kWh}$.

The torque in the graph is like before that the graph trend at the addition of each RPM increases with the addition of the torque and reaches a peak at 1000 RPM like HSD fuel with a value of $33 \mathrm{Nm}$ then after reaching its peak point at 1000 RPM, the torque at each additional RPM continues to experience a decrease in Torque value.

The power generated in the graph above shows that each additional RPM goes hand in hand with the addition of the power generated so that the optimum power occurs at 2200 RPM with HSD getting the highest power with $6.37 \mathrm{~kW}$ then $\mathrm{C} 20$ with $6.01 \mathrm{~kW}, \mathrm{~B} 305.98 \mathrm{~kW}$, $\mathrm{C} 305.97 \mathrm{~kW}$, and the lowest $\mathrm{C} 40$ is $5.8 \mathrm{~kW}$

From the graph and the explanation mentioned above, the optimum power is obtained at the maximum RPM at 2200 RPM, then for the maximum torque is at 1000 RPM, and the optimum SFOC is at 1700 RPM. From these three things, we can take an optimum RPM point, which can optimize power, SFOC, and torque, namely at $1800 \mathrm{RPM}$, where for HSD, the torque obtained is $30.2 \mathrm{Nm}$, the power obtained is $5.71 \mathrm{~kW}$, and the SFOC consumed is $225 \mathrm{gr} / \mathrm{kWh}$. Then from 4 alternative fuels where the most optimum C20 gets power at $1800 \mathrm{RPM}$ of $5.48 \mathrm{~kW}$, the torque obtained is $29.0 \mathrm{Nm}$, and Fuel Consumption (SFOC) is $234 \mathrm{gr} /$ kWh.

\section{Conclusion}

The conclusions that can be drawn from this research are as follows:

1. In terms of performance with alternative fuels other than HSD, the C20 produces an optimum value with a low SFOC value with a value of $238 \mathrm{gr} / \mathrm{kWh}$ at a maximum load 2200 rotation. slightly higher than $\mathrm{HSD}$ at $224 \mathrm{gr} / \mathrm{kWh}$

2. The result of 4 alternative fuels besides HSD, C20, produces higher power than other alternative fuels. It produces a value of $6.0 \mathrm{~kW}$ which is slightly lower than the HSD at $6.35 \mathrm{~kW}$

3. The maximum torque is generated at an engine speed of 1000 RPM. The torque produced at 1000 RPM rotation speed from 4 alternative fuels other than the HSD C20 produces the highest value of $31.7 \mathrm{Nm}$, slightly lower than the HSD at $33.0 \mathrm{Nm}$.

\section{REFERENCES}

[1] Atsonios, K., Kougioumtzis, M.A., Panopoulos, K.D., and Kakaras, E., 2015. Alternative thermochemical routes for aviation biofuels via alcohols synthesis: process modeling, techno-economic assessment, and comparison. Applied Energy, 138, pp.346-366.

[2] Sadef, Y., Nizami, A.S., Batool, S.A., Chaudary, M.N., Ouda, O.K.M., Asam, Z.Z., Habib, K., Rehan, M. and Demirbas, A., 2016. Waste-to-energy and recycling value for developing integrated solid waste management plan in Lahore. Energy Sources, Part B: Economics, Planning, and Policy, 11(7), pp.569-579.

[3] Nurdianto, P., Nugraheni, I.K. and Ivana, R.T., 2016. Pengujian Bahan Bakar Biofull Hasil Pirolisis Botol Plastik Pada Sepeda Motor. Jurnal Elemen, 3(1), pp.01-06.

[4] Demirbas, A., 2015. Pyrolytic distillation of No. 4 fuel oil. Petroleum Science and Technology, 33(17-18), pp.1611-1618.

[5] Raheman, H., Jena, P.C. and Jadav, S.S., 2013. Performance of a diesel engine with blends of Biodiesel (from a mixture of oils) and high-speed diesel. International Journal of Energy and Environmental Engineering, 4(1), p.6

[6] Rifaldi, 2018. produksi bahan bakar cair dari limbah plastik pp dan ko-reaktan minyak jelantah menggunakan metode konversi katalitik, Departemen Kimia. Fakultas Sains. Institut Teknologi Sepuluh Nopember, Surabaya.

[7] Gamma Technologies, 2016, Engine Performance Application Manual, Westmont: Gamma Technologies LLC.

[8] National Institute of Standard and technology, "Isothermal Properties for Propylene," $11 \quad 8 \quad 2020 . \quad$ [Online]. Available:https://webbook.nist.gov/cgi/fluid.cgi?TUnit=K\&PUnit=MP a\&DUnit $=$ mol\%2Fl\&HUnit $=\mathrm{kJ} \% 2$ Fmol\&WUnit $=\mathrm{m} \% 2$ Fs \& VisUnit $=\mathrm{u}$ $\mathrm{Pa}^{*}$ s\&STUnit=N\%2Fm\&Type $=$ IsoTherm $\&$ RefState $=$ DEF $\&$ Action $=\mathrm{Pa}$ ge $\&$ ID $=\mathrm{C} 115071$.

[9] McCrady, J.P., Hansen, A.C. and Lee, C.F., 2007. Modeling biodiesel combustion using GT-Power. In 2007 ASAE annual meeting (p. 1). American Society of Agricultural and Biological Engineers.

[10] pertamina, 2006, Pertamina Industrial Fuel Pertamina dex, Pertamina industrial Fuel marketing, jakarta,

[11] A. H. Muwaffaq, 2016, Prediksi Performa Marine Diesel 4 , Surabaya: Departemen Teknik Sistem Perkapalan, Fakultas Teknologi Kelautan, Institut teknologi Sepuluh Nopember, Surabaya. 